DAVOR SALIHOVIĆ

The Process of Bordering at the Late FifteenthCentury HungarianOttoman Frontier 
DAVOR SALIHOVIĆ

UNIVERSITY OF CAMBRIDGE

UDC 94(439:560)"14"

https://doi.org/10.32728/flux.2019.1.5

Original scientific paper

\section{The Process of Bordering at the Late Fifteenth-Century Hungarian-Ottoman Frontier}

Following the Ottoman conquest of the Despotate of Serbia in 1459 and the Kingdom of Bosnia in 1463, a new phase of Hungarian-0ttoman relations was introduced. With the disappearance of the Hungarian "buffer" towards the Ottoman-held areas, the territories of the two states became adjacent, and their mutual frontier had to be negotiated afresh. By looking into all available material, Latin, Slavonic, and Ottoman, this paper aims to trace negotiations between the two sides in the period of King Matthias Corvinus' reign and discern their content and application with regard to borders. It tackles the demarcation of the border between the two sides, and highlights the mechanisms employed for its institutional maintenance. 
In his study on Hungarian border castles András Kubinyi asserted, albeit somewhat cautiously, that

\begin{abstract}
Wir wissen von der Grenzburgenlinie Ungarns zur Türkenzeit relativ viel. In zahlreichen Arbeiten wurde die Organisation der Grenzverteidigung sowie die Grenzverteidigung selbst allgemein bekannt gemacht. Viel weniger bekannt ist aber die Grenzburgenlinie [...]. Wir kennen zwar die Heeresorganisation gut, aber die Grenzfestungen in viel geringerem Maße. ${ }^{1}$
\end{abstract}

Just as he was quite confident about both the quantity and quality of studies on the "military organisation" of the Hungarian defensive system against Ottoman intrusions, while still stressing their shortcomings, we may claim that while much is known about Hungarian-Ottoman late medieval conflict(s) as well as, to a lesser extent, their diplomatic relations, questions about borders and bordering glimmer in the shadow of these issues. ${ }^{2}$ If we inserted "diplomatic relations and personnel" instead of "military organisation," and "bordering" instead of "border castles" in Kubinyi's claim, we could recycle it. Put differently, the border-related arrangements of the two polities were largely dealt with in studies dedicated to their diplomatic relations, whose primary interest was, however, the personnel, the chronology, and usually only a general overview of the content of negotiations and correspondence. ${ }^{3}$ Although the truces reached by the two sides, relatively well-recorded in sources, are duly mentioned in both the monographs on the medieval history of the Kingdom of Hungary (and its constituent lands) and more narrowly focused studies, they were often chronologically misplaced, their content was marginalized or left under-researched, and, most importantly, the issue was not investigated within the framework of current frontier and border studies. We are, thus, left with a considerable gap in our understanding of not only border-related arrangements of the two opposing sides, but also of bordering processes along the borderlands of the two polities.

The Hungarian-Ottoman bordering of the late fifteenth century, a result of policies conducted by king Matthias and sultans Mehmed II and Bayezid II, was but a moment in a far longer bordering process along the

1 The original study was published in Hungarian as "Magyarország déli határvárai a középkor végén," Várak a későközépkorban - Die Burgen im Spätmittelalter. Castrum Bene 2 (1990): 65-76; reprinted under the same title in Kubinyi's own Nándorfehérvártól Mohácsig - A Mátyás és a Jagelló-kor hadtörténete [From Belgrade to Mohács - War history of Matthias's and Jagiellonian period] (Budapest: Argumentum, 2007), 71-9. The quote was taken from the German version of the paper: "Die südlichen Grenzfestungen Ungarns am Ende des Mittelalters," in András Kubinyi, Matthias Corvinus: Die Regierung eines Königreichs in Ostmitteleuropa 1458-1490(Budapest: Herne, 1999), 188-201.

2 All works on the Hungarian-Ottoman conflict(s) are far too numerous and too scattered to be listed here. The most recent detailed overview is Tamás Pálosfalvi's, From Nicopolis to Móhacs: A History of Ottoman-Hungarian Warfare, 1389-1526 (Leiden and Boston: Brill, 2018). See also: Ferenc Szakály, Pál Fodor, "A kenyérmezei csata (1479. Október 13.)" [The Battle of Kenyérmezö (13 October 1479)], Hadtörténelmi Közleméynek 111(1998): 309-48; and, for a brief overview of the entire period, Ferenc Szakály, "Phases of Turco-Hungarian Warfare Before the Battle of Mohács (1365-1526)," Acta Orientalia Academiae Scientiarum Hungaricae 33 (1979): 65-111.

3 See, primarily, László Fenyvesi, "Magyar-török diplomáciai kapcsolatok Mátyás király haláláig," [Hungarian-Turkish diplomatic relations until the death of king Matthias], Hadtörténelmi Közlemények 103 (1990): 74-99; Vilmos Fraknói, "Mátyás király magyar diplomatái" [King Matthias's Hungarian diplomats], Századok 32 (1898): 1-14, 97-112, 385-404, 481-9, 769-81, 865-75; Századok 33 (1899): 1-8, 291-309, 389-410; 773-87, 869-78; Gyula Rázsó, "Hunyadi Mátyás török politikája," Hadtörténelmi Közlemények 22 (1975): 305-48, or the German version "Die Türkenpolitik Matthias Corvinus," Acta Historica Academiae Scientiarum Hungaricae 32 (1986): 3-50. 
territorial edges of the Kingdom of Hungary. Recently approached through a concept of border territorialisation, ${ }^{4}$ this process, lasting for at least four centuries by the time of Matthias' contributions, rearranged both spatial, functional, institutional, societal, and symbolic aspects of the borders of the kingdom. Starting with a vague system of gyepü and gyepüelve, a spatial and possibly territorial ${ }^{5}$ stretch of underpopulated zones and porous points surrounding the kingdom in, roughly, the first two centuries of its existence, and continuing with a conceptually even vaguer system of southern buffers, which was developed with special care during the late Anjou period and especially during king Sigismund's reign when its organisation almost solely depended on the pressure applied by the Ottomans, ${ }^{6}$ it came to a temporary and relative rest in the period of our interest when the southern border's institutional character was defined in far clearer terms than before. It is important, however, to note that all these incarnations of the kingdom's borders and related systems are yet to be scrutinized and researched within the theoretical framework(s) of present-day border studies. Current knowledge on the issue rests upon long outdated historiographical, concepts and research methods. It, therefore, still awaits an investigation which would penetrate beyond classical historiographical methods, with an affinity for both the questions raised in frontier studies and methods belonging to the field of digital, spatial or linguistic history. Although I have applied the latter in some of my other writings (including a version of this paper included in the thesis), here I shall focus on the former, due primarily to the limited space of this paper.

\section{Research Questions and Conceptual Guidelines}

While a detailed analysis of the Hungarian-Ottoman bordering prompted by a variety of questions present in current border studies is

4 Nora Berend, "L'évolution de la territorialisation dans le défense de la Hongrie du XIIIe au XVIe siècle," in Entre Islam et Chrétienté: La territorialisation des frontières, Xle - XVIe siècle, eds. Stéphane Boissellier and Isabel Cristina Ferreira Fernandes (Rennes: Presses Universitaires de Rennes, 2015), 217-32.

5 The concept of territory or, rather, territoriality used here corresponds to an institutional and strategic phenomenon discussed in Robert David Sack, Human Territoriality: Its Theory and History (Cambridge: Cambridge University Press, 1986.)

6 For an overview see: András Borosy, "Határörség és határőrök az Árpádok korában" [Border protection and border guards in the Árpád period], Hadtörténelmi Közlemények 24 (1977): 543-57; József Deér, "Zsigmond király honvédelmi politikája" [King Sigismund's defensive policy], Hadtörténelmi Közlemények 37 (1936), 1-57, 169-202; Hansgerd Göckenjan, Hilfsvölker und Grenzwächter im mittelalterlichen Ungarn (Wiesbaden: Franz Steiner, 1972), especially 5-22; Neven Isailović, "Living by the Border: South Slavic Marcher Lords in the Late Medieval Balkans (13 $13^{\text {th }}-15^{\text {th }}$ Centuries)," Banatica 26 (2016): 105-17; Gyula Kristó, Ferenc Makk, and László Szegfü, "Szempontok és adatok a korai magyar határvédelem kérdéséhez" [Views and data on the issue of early Hungarian border defence ], Hadtörténelmi Közlemények 20 (1973): 639-58; Karl Tagány, "Alte Grenzschutz-Vorrichtungen und Grenz-Ödland: gyepü und gyepüelve," Ungarische Jahrbücher 1 (1921): 105-21; Ferenc Szakály, "The Hungarian-Croatian Border Defense System and its Collapse," in From Hunyadi to Rákóczi: War and Society in Late Medieval and Early Modern Hungary,eds. János M. Bak and Béla K. Király, (Brooklyn: Brooklyn College Press, 1982), 141-158; Atilla Zsoldos, "Confinium és marchia (Az Árpád-kori határvédelem néhány intézményéröl)" [Confinium and marchia (Some institutions of borderprotection of the Árpád period)], Századok 134 (2000): 99-116. 
necessary, the agenda of this paper is rather narrow and focused on the nature, function, and some institutional features of the border as designed by the bordering authorities of the two sides in the period from c. 1460 to c. 1490 . The primary sources for the study, which will be introduced later in greater detail, are largely comprised of (diplomatic) correspondences, narrative sources pertaining to the period, and a variety of other diplomatic materials, including council minutes from Ragusa, Ottoman fermans, charters produced by the royal chancery or decrees passed by the diet. With the exception of truces and border-related negotiations of the 1480s, no explicit documents on such arrangements themselves from a preceding period have come to us, which evidently implies a utilization of a variety of sources which could, if properly arranged, allow for a closer look despite the obscurity of available data.

Probably well known to both specialists as well as occasional adventurists in frontier studies is the age-old question within historiography on the zonality or the linearity of medieval borders as well as further questions about sovereignty, power relations, nature of international relations, political paradigms, and administrative organization. Since works on these issues are far too numerous to be discussed here, I shall merely mention a paper which, among many introductory chapters to collections on frontiers, seems to be the most valiant attempt at reconciling the two views (zonal/linear), Pierre Toubert's Frontière et frontières: un objet historique. ${ }^{7}$ While acknowledging the complexity of the issue of borders, Toubert, finding an authority in and largely paraphrasing Friedrich Ratzel's Politische Geographie, ${ }^{8}$ suggests that Grenzsaum and Grenzlinie must be two relatively distinct phenomena pertaining to reality and an abstraction from reality, respectively. The latter, as Toubert and Ratzel would have it, serves to (re)produce abstract spatial fixations in accordance with societal or political agendas. Leaving aside further questions raised by such an assertion, we shall put our sources to the test and try to discern whether the border dividing the Kingdom of Hungary from the Ottoman Empire, as it was conceived and designed by their respective authorities, had any zonal or linear quality; if it did, was any of the two exclusively represented, or were the two arranged in a certain relation; or, finally, was there a zonal reality and a linear abstraction.

Another set of questions pertains to the role assigned to the border by the bordering authorities. What was long discussed in geographical studies on borders as well as within the international relations theory, and put under an overarching (economic) flow approach with a crucial concept of borders as places of discontinuities in politically disjointed but otherwise homogeneous spaces was utilized most recently by Thomas Nail. ${ }^{9}$ In his contribution to the theoretical treatment of borders titled Theory of the Border, Nail does a fine

7 Pierre Toubert, "Frontière et frontières: un objet historique," in Castrum 4. Frontière et peuplement dans le monde méditerranéen au Moyen Âge, ed. Jean-Michel Poisson (Rome and Madrid: École française de Rome and Casa de Velázquez, 1992), 9-17.

8 Friedrich Ratzel, Politische Geographie oder die Geographie der Staaten, des Verkehres und des Krieges (Munich and Berlin: R. Oldenbourg, 1903).

9 For a brief introduction see: Henk van Houtum, "An Overview of European Geographical Research on Borders and Border Regions," Journal of Borderlands Studies 15 (2000): 57-83. 
(although almost comedically verbose) job in summarizing the role of the border in (largely present-day) societies and polities, as it was assumed half a century ago. In short, the border, eventually, forms a junction (or a series of junctions) in the local or broader "kinopolitics" (or politics of movement); or, in plain language, the border is a more or less (and always) porous obstacle which impedes an otherwise unobstructed movement of either peoples, goods, or anything that may be put in motion and travel from one point to another. ${ }^{10} \mathrm{If}$, then, the role of the border is to act more or less porously against cross-border motion, we shall examine whether such a role was assigned to the Hungarian-Ottoman border, and to what extent. In other words, we shall put Nail's conceptual framework to the test against the data from available sources to discern the border's role.

Finally, recent trends in border studies, partly oriented towards the research of border performativity or the capacity of certain individuals, groups, or institutions to perform the border at different levels or with various amounts of autonomy or potential, prompted a final set of questions regarding the authorities which in these specific cases designed and guided the bordering process in accordance with their capacity in performing the border." As these questions pertaining to the framework of border studies deserve a far longer discussion than we would be able to present here, and since they will be discussed in far more detail in my other papers, I shall only include a shorter analysis of authorities here, and largely of those on the Hungarian side.

In short, I shall attempt to discern whether and to what extent was the Hungarian-Ottoman border of the late fifteenth century zonal or linear; what was the role assigned to it by the bordering authorities; and who might have these authorities been.

\section{Chronological Overview of Negotiations}

Already in the autumn of 1461 there were some thoughts of a possible truce between the king and the sultan in Venice, ${ }^{12}$ and in December of the same year Duke Stephen Kosača informed the Venetian government that after the sultan had conquered Serbia he made peace with the king, according to rumours. ${ }^{13}$ Two years after the Ottoman conquest of Bosnia in 1463, and a little less after Matthias' acquisition of Jajce and failure at Zvornik, ${ }^{14}$ when he made further steps towards the southwest of Bosnia,

10 Thomas Nail, Theory of the Border (Oxford: Oxford University Press, 2016), 21-45.

11 Cf. Noel Parker, Nick Vaughan-Williams, "Lines in the Sand? Towards an Agenda for Critical Border Studies," Geopolitics 14 (2009): 582-7; idem, "Critical Border Studies: Broadening and Deepening the Lines in the Sand Agesnda," Geopolitics 17 (2012): 727-33.

12 Iván Nagy, Albert Nyáry, Monumenta Hungariae historica, vol. IV. Acta extera: Magyar diplomacziai emlékek Mátyás király korából [ Hungarian diplomatic memories from the period of king Matthias ], vol. I (Budapest: MTA, 1875), doc. 63, 92-3. Ibid., doc. 67, 101-3.

14 Briefly on king Matthias's actions in Bosnia in 1463 and 1464 see: József Bánlaky, "Az 1463. évi délvidéki és boszniai hadjárat. Az ugyanezen évi tolnai országgyülés határozatai" [Southern and Bosnian campaign of 1463. Decisions of the Diet of Tolna in the same year]; "Az 1464. évi boszniai hadjárat" [ The campaign in Bosnia of 1464], in idem, A magyar nemzet hadtörténelme, accessed January 7, 2018, https://www.arcanum.hu/hu/online-kiadvanyok/ Banlaky-banlaky-jozsef-a-magyar-nemzet-hadtortenelme-2/; Emir 0. Filipović, "Minor est 
the sultan sent him an ambassador who, according to a report by Gerard de Colli to the duke of Milan, offered the king the whole of Serbia and Bosnia should he be willing to sign a truce. ${ }^{15}$ As much as half a year before Gerard dispatched his report, the king himself, in a response to Venetian claims that diversis modis tentati fueramus de pace cum Turco, ${ }^{16}$ soothed doge Cristoforo Moro by informing him that he had also received offers in the years after 1463, and was not merely tentatus, but was paene infestatus by constant offerings. ${ }^{17}$ The king claimed that offers for peace came through the voivode of Wallachia, as well as through Bosnia, the despot of Serbia, ${ }^{18}$ and by way of envoys of Hungarian barons holding offices at the border. ${ }^{19}$ Still, already in the same letter Matthias assured his allies that he strongly rejected all of these offers, and Gerard ends his report on the issue by stating that the king was not willing to accept any propositions presented by the ambassadors. ${ }^{20}$

In 1466, the Venetians were again aware of the possibility that the king might be concluding a truce with the Ottomans per medium of a certain Radovich, ${ }^{21}$ and similar news reached them in the summer of 1467 when they informed their ambassador at Matthias' court not to meddle with that business. ${ }^{22}$ Further information on the progress of negotiations comes from a charter produced by Matthias' own chancery in October of the same year by which the king gives Nicholas Újlaki, then a perpetual count of Teočak, a permission to establish a marketplace at Apayoch, a ford on the Sava (today

Turchorum potentia, quam fama feratur... Contributions to the History of Bosnia in the Second Half of 1463"; Aleksandar Jakovljević, "Između osmanskog i ugarskog krajišta: osmansko zaposedanje Podrinja i ugarska opsada Zvornika 1464. godine, in Pad Bosanskog kraljevstva 1463. godine, (Belgrade-Sarajevo-Banja Luka: Istorijski institut Beograd-Filozofski fakultet u Sarajevu-Filozofski fakultet u Banjoj Luci, 2015), 195-226; 227-57; Lajos Thallóczy, Povijest (banovine, grada i varoši) Jajca 1450.-1527. [History of the (banate, castle, and town) of Jajce 1450-1527](Zagreb: Kraljevska zemaljska tiskara, 1916), 75-85; T. Pálosfalvi, From Nicopolis to Mohács, 208-21.

15 Nagy, Nyáry, Magyar diplomacziai emlékek I, doc. 215, 351-2.

16 Ibid., doc. 187, 307-8.

17 Vilmos Fraknói, Mátyás király levelei. Külügyi osztály [The letters of king Matthias. Foreign affairs ], vol. I(Budapest: MTA, 1893), doc. 59, 77-9.

18 Cf.Katarina Mitrović, Mitrović, "Vuk Grgurević između Mehmeda II. i Matije Korvina (14581465)," Braničevski glasnik 2 (2003): 28ff. Also: Johann Christian von Engel, Geschichte des ungrischen Reichs vol. III/I (Wien: Friedrich Volke, 1834), 264-5; Aleksa Ivić, Istorija Srba u Vojvodini od najstarijih vremena do osnivanja potisko-pomoriške granice (1703) [History of Serbs in Vojvodina from the earliest times to the establishment of Potisje-Pomorišje border (1703)] (Novi Sad: Matica srpska, 1929), 16; Johann Wilhelm Zinkeisen, Geschichte des osmanischen Reiches in Europa vol. II (Gotha: Friedrich Andreas Perthes, 1854), 175-6.

19 Fraknói, Mátyás király leveleil, doc. 59, 78.

20 Nagy, Nyáry, Magyar diplomacziai emlékek I, doc. 215, 351-2.

21 Šime Ljubić, Monumenta spectantia historiam Slavorum meridionalium, vol. XXII. Listine o odnošajih između Južnoga Slavenstva i Mletačke Republike [Documents on the relations between the South Slavs and the Republic of Venice ], vol. X (Zagreb: JAZU, 1891), doc. 367, 360-2. Ibid., doc. 415, 397-8. 
Opojevci in Serbia), ${ }^{23}$ as soon as the trewga conclusa fuerit ita. ${ }^{24}$ While the king was still recovering from a failed attempt at organizing yet another military action, possibly even a crusade against the Ottomans in alliance with the Germans, as well as from a recent Transylvanian rebellion and a heavy defeat in Moldavia, ${ }^{25}$ Gerard de Colli dispatched two reports in February 1468 by which he informed his lord in Milan that the "captain" (probably sanjak-bey) of Smederevo sent an envoy to the king to ask for truce, after what seems to be initial meetings in Nagyvárad in January. ${ }^{26}$ According to Gerard's reports, since the king was occupied elsewhere, he returned having achieved nothing. In his next report from the same month Gerard sent words about the pope's discontent with Matthias' negotiations with the Ottomans about a truce, but, while trying to persuade Galeazzo Maria Sforza to help Matthias in his fight against the Turks, he also speaks of the king's dissatisfaction with the pope's correspondence and willingness to strike a deal with the enemy or otherwise va ad pericolo de perdere tuto lo reame. ${ }^{27}$

While Gerard gathered his information from rumours and quotidian curial chat rather than from official royal documents, and he was stationed in Venice, not at the king's side, the Venetians were already in December 1467 informed through much more trustworthy channels that the details about the truce were already agreed upon, and that only a final corroboration remained. ${ }^{28}$ The king, reportedly, continued to exchange envoys with the sultan in the spring of $1468,{ }^{29}$ and in March Gerard once again informed Milan of a talk about a Hungarian (and Venetian) truce with the Ottomans, for which his best source of information was the "one who recently arrived from Hungary" and "saw the king with the Ottoman envoy" in Nagyvárad. ${ }^{30}$ The most exhaustive of all of Gerard's reports continues with a description of negotiations during which the sultan's envoy demanded the surrender of Jajce and offered Smederevo in exchange only to obtain an unobstructed passage towards Istria. ${ }^{31}$ Still, apart from a yet another report by Gerard de

23 Dezső Csánki, Magyarország történelmi földrajza a Hunyadiak korában [Hungarian historical geography in the Hunyadi period], accessed January 8, 2018, https://www.arcanum.hu/en/ online-kiadvanyok/Csanki-csanki-dezso-magyarorszag-tortenelmi-foldrajza-a-hunyadiakkoraban-1/ii-kotet-32A7/valkovarmegye-426B/helysegei-42DC/?list=eyJmaWxOZXJzljogey JNVSI6IFsiTkZPXOtPTIIfO3NhbmtpXzEiXXOsICJxdWVyeSI6ICJvcG9qZXZjKiJ9,s.v. Apajócz; Opoj(-favla).

24 Lajos Thallóczy, Antal Áldásy, Monumenta Hungariae historica, vol. XXIII. Codex diplomaticus partium Regno Hungariae adnexarum, vol. II. Magyarország és Szerbia közti összeköttetések oklevéltára 1198-1526 [Diplomas on the Hungarian-Serbian relations], (Budapest: MTA, 1907), doc. $356,257-8$.

See: Nicolae lorga, Notes et extraits pour servir à l'histoire des Croisades au XVe siècle vol. IV (Bucharest: Academia Română, 1915), 250-70; Jovanka Kalić-Mijušković, Beograd u srednjem veku [Belgrade in the middle ages] (Belgrade: Srpska književna zadruga, 1967), 192-3; A. Kubinyi, Matthias Rex(Budapest: Balassi kiadó, 2008), 73-93. Nagy, Nyáry, Magyar diplomacziai emlékek II, docs. 59 and 60, 92-5.

loan-Aurel Pop, Alexandru Simon, "The Venetian and Wallachian Roots of the HungarianOttoman Truce of Spring 1468: Notes on Documents from the State Archives of Milan," in Italy and Europe's Eastern Border (1204-1669), eds. Iulian Mihai Damian et al. (Frankfurt am Main: Peter Lang, 2012), doc. 3, 290-2.

Ljubić, Listine, doc. 420, 402-3.

Ibid., doc. 425, 406-7.

Nagy, Nyáry, Magyar diplomacziai emlékek II, doc. 47, 78-81.

lbid., 79-80. 
Collis, sent in January before he asserted that the negotiations had failed due to the king's business in Transylvania, in which he states that "it is said" that the barons have rebelled against the king because of his truce with the Ottomans, there are no other sources, including his report from March, which would confirm that these negotiations were fruitful. ${ }^{32}$ Gerard also wrote, however, that the real reason for the barons' dissatisfaction must have been the king's favouritism towards Tucianus and Rosgonianus, i.e. John Thuz and John Rozgonyi.

Despite the lack of sources which would unequivocally confirm such a conjecture, it has been claimed that a truce might have been or even had been achieved in 1468, or even earlier. ${ }^{33}$ On the contrary, Gerard's reports, which, untrustworthy as they may be, remain the only source of information on the conclusion of negotiations suggest that the whole endeavour failed or, at least, ended with an indeterminate conclusion. László Fenyvesi, one of a couple of scholars who seem to be the most ardent advocates of the existence of a truce of 1468, claimed in his brief overview of HungarianOttoman diplomatic relations that the truce was indeed achieved, pointing to the errors of previous scholarship. ${ }^{34}$ Relying on the same sources which are available to us, and especially on king Matthias' charter addressed at Nicholas Úlaki regarding the market at Apajócz, Fenyvesi failed to notice that these documents speak of a truce with anticipation. More recently, loan-Aurel Pop and Alexandru Simon accepted the truce of 1468 as fact without providing any additional proof apart from the Milanese ambassador's dispacci, and maintain that this was a two-year truce which was then prolonged in 1470 and 1472. ${ }^{35}$ The same lack of definite evidence for a clear conclusion of HungarianOttoman negotiation with a truce goes, however, for both of those years and, for that matter, for the larger part of the decade until 1478.

Some news about the king of Hungary signing an "accord" with the Ottomans reached Milan in July $1471,{ }^{36}$ and Tursun Beg writes about a Hungarian diplomatic mission in Istanbul in 1470 or 1471.37 The king's ambassadors have probably continued the talks with the Ottomans in $1472 / 1473$ in the midst of western, primarily Venetian and, to a lesser extent, Hungarian plans for a closer cooperation with Uzun Hassan in a coordinated attack against the mutual enemy. ${ }^{38}$ The king certainly sent envoys in 1473 , as both the sources from his own chancery, further diplomatic reports,

\footnotetext{
32 Ibid., doc. 58, 91-2.

33 Even in, for instance, as extensive but cursory works as Pál Engel, The Realm of St Stephen: A History of Medieval Hungary, 895-1526 (London and New York: I. B. Tauris, 2001), 327.

34 Fenyvesi, "Magyar-török," 83-4.

35 Pop, Simon, "The Venetian and Wallachian Roots," 283-301.

36 Nagy, Nyáry, Magyar diplomacziai emlékek II, doc. 163, 225-6.

37 József Thúry, Török történetírók [Turkish historians] vol. I (Budapest: MTA, 1893), 92.

38 On relations between king Matthias and Uzun Hassan see: Lajos Tardy, Beyond the Ottoman Empire: $14^{\text {th }}-16^{\text {th }}$ century Hungarian Diplomacy in the East(Szeged: University of Szeged, 1978), 58-96. On Uzun Hassan in general and his collaboration with the West: Vladimir Minorsky, Clifford E. Bosworth, "Uzun Hasan," in Encyclopaedia of Islam, $2^{\text {nd }}$ ed., accessed January 11, 2018 http://referenceworks.brillonline.com/entries/encyclopaedia-of-islam-2/uzun-hasanSIM_7788?s.num=13; John E. Woods, The Aqquyunlu: Clan, Confederation, Empire (Salt Lake City: The University of Utah Press, 1999), $87 \mathrm{ff}$.
} 
and papal letters confirm, ${ }^{39}$ and some negotiations might have even been conducted on lower administrative levels, since Ragusan minutes suggest there might have been some contacts between ban Damian Horvat and Ayaz, the sanjak-bey of Bosnia. ${ }^{40}$ Furthermore, the abovementioned letter by pope Sixtus IV mentions Ivaniš Vlatković (assuming he hides behind Johannes Hunischi, as Atanasovski suggests), a nobleman from Hercegovina, as one of the king's ambassadors who crossed the Danube near Belgrade in April 1473, while the envoy of Nicholas Újlaki, the king of Bosnia, travelled through Ragusan environs and visited both Ivan Crnojević and Duke Vlatko in December $1472 . .^{41}$ The very same ambassadors who crossed the Danube in April and were mentioned by the pope in his letter were mentioned again in a report to the bishop of Ferrara from Rome, which begins with a claim that the Ottomans have pleaded for a truce but have asked for the intermediation of Nicholas Újlaki, who personally chose the two emissaries, Hunischi included, to go to Istanbul and represent Matthias. ${ }^{42}$ The king, according to the report, would comply with Ottoman requests only if they accepted to give up Bosnia and Serbia, or at least one of these lands. ${ }^{43}$

Not much more, however, can be conjectured from these sources, although some information suggests that the talks of 1472/1473 were initially devised as Mehmed II's tactical trick to prevent any Hungarian interference, as suggested by his actions against the ruler of Aq Ooyunlu in 1473 which later turned into yet another demand for the surrender of Jajce and some other strongholds. The request was, naturally, rejected, and the negotiations failed. ${ }^{44}$

They were, nonetheless, continued in 1475 at the latest. Acquired through trustworthy channels, in October news about the Ottoman offer of a twelve- or seven-year truce in exchange for a free passage through Croatia and Dalmatia, presumably towards Italy and the Empire, reached both Milan

39 Magyar Nemzeti Levéltár, Országos Levéltára [Hungarian national archives, State archives] (Henceforth: MNL, OL], Diplomatikai Fényképgyüjtemény [Diplomatic photo-collection] (Henceforth: DF) 268093; Adolf Bachmann, Fontes rerum Austriacarum. Diplomataria et Acta, vol. 46. Urkundliche Nachträge zur österreichisch-deutschen Geschichte im Zeitalter Kaiser Friedrich III (Vienna: F. Tempsky-Kaiserliche Akademie der Wissenschaften, 1892), doc. 167, 179; Jakov Stipišić, Miljen Šamšalović, "Isprave u Arhivu Jugoslavenske akademije" [Documents in the Archives of the Yugoslav Academy], Zbornik Odsjeka za povijesne znanosti Zavoda za povijesne i društvene znanosti HAZU 3 (1960): doc. 2767, 615; Luke Wadding, Annales Minorum seu Trium Ordinum a S. Francisco institutorum, vol. XIV (Rome: Rocco Bernabò, 1735) 69-72.

40 József Gelchich, Diplomatarium relationum Reipublicae Ragusanae cum Regno Hungariae (Budapest: MTA, 1877), 801.

41 Cf. Veljan Atanasovski, Pad Hercegovine [The fall of Hercegovina] (Belgrade: Narodna knjiga-Istorijski institut u Beogradu, 1979), 93, fn. 51; Državni arhiv u Dubrovniku [State archives in Dubrovnik], Acta Consilii Rogatorum XXI, fol. 227r and 279v; Davor Salihović, "Nonnulla documenta pertinentia ad Nicolaum de Wylak, regem ultimum Regni Bosnae," Scrinia Slavonica 17(2017): 415; also idem, "An Interesting Episode: Nicholas of Ilok's Kingship in Bosnia 1471-1477" (MA Thesis, Central European University, 2016), 72-3; Wadding, Annales Minorum Ordinum XIV, 69. Bachmann, Urkundliche Nachträge, doc. 167, 179.

43 Ibid.

44 Franc Babinger, Mehmed Osvajač i njegovo doba [Mehmed the Conqueror and his time] (Belgrade: Algoritam, 2010), 281-2. 
and Venice, either through the king himself or the bishop of Eger. ${ }^{45}$ In his personal correspondence with the Venetian ambassador, the bishop added that the Ottomans were even promising to surrender a large part of Serbia, ${ }^{46}$ but there are no sources which would confirm a successful conclusion to these negotiations. In December 1476, a certain Vespasiano informs Alfonso, then the Duke of Calabria (future Alfonso II of Naples), that Ottoman emissaries have visited Buda, but no discussions took place and a truce with the Ottomans was not signed. ${ }^{47}$

It should be quite clear by now that the majority of information on negotiations in the period between king Matthias' election and 1476 available to us comes largely from diplomatic correspondence and, apart from several cases, individuals who were not close to the royal court and had nothing to do with royal politics (or the sultan's politics, for that matter). This necessarily labels the bigger part of available sources second-rate at best, and in most cases does not allow for much more than speculation. However, documents pertaining to negotiations in 1478 (1480), 1482/1483 and 1488, although in part similar to the material from the earlier period, largely come from chanceries of the two rulers at issue or are authored by individuals close to the king with decision-making capabilities.

On April 6,1478, Leonard Botta dispatched a message for the duke of Milan by which he informed him of the activities of a Venetian Tomaso Malipieri who, as hopes for a successful collaboration with Uzun Hassan were now completely gone due to his death, came to discuss the Republic's truce with the Ottomans in Istanbul. ${ }^{48}$ More importantly, Leonard added that Hungarian envoys were there as well, and that they, apart from being acharezati et honorati asai et vestiti de brochato d'oro et cremusi, signed a five-year truce with the sultan and took with them an Ottoman ambassador back to Hungary. ${ }^{49}$ An ambassador truly arrived at the king's side in May of the same year to either conclude a peace or prolong the truce, according to a dispatch from Graz. ${ }^{50}$

Far superior sources are, however, the king's own letters sent to Mehmed during the summer of the same year which contain far more reliable information on the issues discussed during negotiations about the truce. The main envoys of the two princes were Peter Dóczi and a certain Gel-beg (or Hed-beg) $)^{51}$ who, as it seems, mediated between the two sides on issues which have arisen after initial regulations pertaining to the truce have been agreed. In other words, the princes seem to have already found a consensus on crucial issues related to the truce, and further problems appeared

\footnotetext{
45 Nagy, Nyáry, Magyar diplomacziai emlékek II, doc. 195, 279-82.

46 Ibid., doc. 198, 285.

47 Ibid., doc. 232, 336-8.

48 Lajos Thallóczy, "Frammenti relativi alla storia dei paesi situati all'Adria," Archeografo Triestino ser. 3, 7 (1914): 85-6; see also: Victor Louis Ménage, "Seven Ottoman Documents from the Reign of Mehemmed II," in Documents from Islamic Chanceries: First Series, ed. Samuel M. Stern (Cambridge, MA: Harvard University Press, 1965), 81-118. See note 39.

49 Thallóczy, "Frammenti relativi," 85-6.

50 Nagy, Nyáry, Magyar diplomacziai emlékek II, doc. 255, 368-9.

51 Fraknói, Mátyás király levelei l, docs. 259 and 281, 381-3, 409. Different spelling in MNL, OL DF 292991, fol. 210r.
} 
only when the two sides failed to fulfil their respective obligations, whose actualization would have opened a way to the truce..$^{52}$ In a letter from August 1478, the king responded to the sultan's request for the demolition of two unnamed fortresses which, as follows from the king's wording, he was obliged to do, according to the agreement, within a month and a half. ${ }^{53}$ However, the king confesses, he halted the destruction due to recent Ottoman incursions in Croatia, where they robbed and burned several villages, captured a castellum, and returned in Turciam with captives and plunder, and urges the sultan to let him know whether he still wishes to adhere to the truce and to compensate the damage in Croatia. Interestingly, the king adds that at the time the sultan's letter reached him, only seven days were left for him to demolish those two fortresses and fulfil his obligations, which would date the truce to June or July 1478.

While Fraknói claims that a second, undated letter pertaining to Dóci's mission confirms that the sultan agreed to the king's proposals and a truce was achieved, ${ }^{54}$ it has been suggested, although it seems from the king's letters that at least some basic regulations have been arranged, that a later letter sent by Stephen Bátori during the negotiations of 1482/1483 reveals that the two sides came close to signing a treaty, but the abovementioned issues caused them to abandon it. ${ }^{55}$ In his letter, Bátori indeed writes about a certain truce which had to be terminated due a sudden change in sultan's demands after these preconditions were already agreed upon, while the other side claims that the king's failure to comply with the terms caused the rupture. ${ }^{56}$ More importantly, it is noted that the king's unfulfilled obligation was to tear down "gra(d) Zaslonb ĉo je s oni strane uzetı ôd vas" (the castle of Zaslon which was taken from you "on the other side", i.e. south from the Sava), ${ }^{57}$ which the king not only promised to comply with before the sultan's envoy, but was also written in contracts, while the true cause of the rupture was, according to Bátori, the sultan's demand that;

[...] kako da bi njegova voiska ka(d) je bilo njemu drago da hodi skrozê zemlû i $\mathrm{gp}(\mathrm{s})$ tvo svtlosti kraljevje, s volo(m) kraljevo(m), ili i bez volje.

$[\ldots]$ his army passes through the land and the lordship of His Majesty at his own (i.e. sultan's) will, either with the king's permission or without it.

The king's envoy to whom these demands were presented was,

52 Ibid., doc. 263, 387-9.

53 Ibid.

54 V. Fraknói, "Mátyás király magyar diplomatái," 870-1.

55 Jovanka Kalić, ed., Istorija srpskog naroda vol. 2: Doba borbi za očuvanje i obnovu države (1371-1537) [History of the Serbian nation: The Period of struggle for the preservation and restoration of the state (1371-1537)] (Belgrade: Srpska književna zadruga, 1982), fn. 36, 385; cf. Katarina Mitrović, "Pet pisama despota Vuka Grgurevića" [Five letters by Despot Vuk Grgurević ], Braničevski glasnik 3-4 (2004-2005): 63-83.

56 Nikola Radojčić, "Pet pisama s kraja XV. veka" [Five letters from the end of the fifteenth century], Južnoslovenski filolog 20 (1953-1954): 362-3. Quotes from the letters transliterated by me from the Cyrillic script.

On the capture of Šabac, see: László Veszprémy, "Szabács ostroma (1475-1476)" [The siege of Šabac ], Hadtörténeti Közlemények 122 (2009): 36-61; Dezső Csánki, "Szabács megvétele," [The fall of Šabac ], Hadtörténelmi Közleméynek 1(1888): 355-88; Sima Ćirković, "Srednji vek" [The medieval period], in Šabac u prošlosti [The history of Šabac], ed. Stanoje Filipović (Šabac: Istorijski arhiv, 1970), 93-101. 
according to Bátori, none other than Peter Dóci, the envoy from the 1478 negotiations, which then strongly suggests that the truce at issue was one discussed during the summer of the same year. However, while these demands are missing from the correspondence of 1478, in 1480 the king sent yet another letter to the sultan by which he informs him that he had received his letter "a few days ago" by which the sultan beseeches him to reopen negotiations about a truce which had been discussed at some point in the past, probably in $1478 .^{58}$ The king continues that this petition came through Dawth bassa (Davud Pasha, then the sanjak-bey of Bosnia) and through the king's ban of Bosnia, a position held at that time by Dóci, and that the sanjakbeg, during these negotiations, demanded a free passage through the king's lands to the domains of the Emperor as part of the deal, which the king not only granted, but had ordered his own men not to obstruct the sanjakbey's plans in any way. However, Davud broke the deal by causing damage to the king's own lands, which resulted in a short quarrel. ${ }^{59}$ Nevertheless, the negotiations were continued, and even though the king's envoy had been waiting in Jajce for six weeks, the sanjak-bey, according to Matthias, constantly excused himself and refused to meet him. ${ }^{60}$

Although Bátori in 1482 claimed that the king strongly rejected the sultan's demands for free passage, it seems that his letter bridges the gap between the talks in 1478 and 1480, and it is possible, assuming such demands were not dispatched as early as 1478 or the next year, that the events of 1478 and 1480 form a part of one and the same negotiations. ${ }^{61}$ Such a sequence of events would suggest that a complete truce was never achieved. In other words, even though the two sides consented to most of the terms, both were at pains to compel the other side to fulfil their respective obligations, such as halt intrusions or demolish fortresses.

The talks were continued, as mentioned, in 1482/1483, when a certain role was played by despot Vuk Grgurević, then the "captain of Bosnian fortresses," as well as by Bátori. Vuk's own letters sent during that period to the sultan, now Bayezid II, show that he was one of the main (if not the sole) brokers of the deal between the two rulers, and that initial plans even considered restoring the Despotate of Serbia which would be put under Vuk's rule, providing that he manages to facilitate a successful conclusion of negotiations. ${ }^{62}$ Other elements of these talks will be discussed in detail in the next section, but it is important to emphasize that an agreement was eventually reached, and a truce was concluded in 1484, at the latest. It was, as sources suggest, prolonged in 1488 and lasted until king Matthias's passing in $1490 .{ }^{63}$

\footnotetext{
58 Fraknói, Mátyás király levelei II, doc. 247, 388-90.

59 This must be referring to Davud's two akins into Carniola and Styria, and Hungary of 1479 and 1480. See: Dušanka Bojanić, "Dve godine istorije Bosanskog krajišta (1479. i 1480.) - prema Ibn-Kemalu" [ Two years in the history of the Bosnian march (1479 and 1480) according to Ibn-Kemal], Prilozi za orijentalnu filologiju 13-15 (1964): 33-50; Stanko Jug, "Turški napadi na Kranjsko in Primorsko do prve tretjine 16. stoletja" [Turkish attacks on Carniola and Primorska until the first third of the $16^{\text {th }}$ century], Glasnik Muzejskega društva za Slovenijo 24 (1943): 1-61.

60 Ibid.

61 See above, note 57.

62 Ibid., 353.

63 See: Fraknói, Mátyás király levelei II, doc. 169, 286; György Hazai, "A Topkapu Szeráj Múzeum
} 


\section{The Bordering}

In one of his rare papers translated into English, French-Swiss geographer Claude Raffestin, a largely neglected figure in anglophone scholarship, presents a three-stage process of "fixing a frontier," albeit in societies of the nineteenth and later centuries "when linearity became accepted." ${ }^{64}$ The concept, which was later utilized by Edoardo Grendi in his La pratica dei confini: Mioglia contro Sassello, $1715-1745,{ }^{65}$ implies the stages of definition (a series of negotiations which define the border in loose terms in treaties), delimitation (mapping of the border), and demarcation (of the border in real space, using terrain or objects, natural or man-made). Sources at our disposal do not allow for a detailed research of all of these stages in our particular case, especially since Raffestin reserved the second stage for periods of well-developed cartography. There was, on the other hand, an already touched upon and by the late fifteenth century largely standardized process of negotiations within the 0 ttoman diplomatic practice. ${ }^{66}$ Initiated by the interested side, the negotiations were usually conducted through envoys and by the exchange of temessük or provisional drafts, until an agreement was reached and the princes issued capitulations or an 'ahdname, confirming their content by a swearing of an oath. At times, if suitable, truces were followed by crude demarcations noted in the so-called hudud-or sinur-name (lit. 'letter of boundaries'), ${ }^{67}$ such as a contemporary, and relatively detailed Venetian sinur-name of 1479 , compiled at the Porte after the conclusion of the peace of the same year. ${ }^{68}$ Although no such detailed document, nor of

levéltárának magyar vonatkozású török iratai" [Turkish documents in the archives of the Topkapı Palace Museum with relevance to Hungary], Levéltári Közlemények 26 (1955): 2915; Imre Kelcz, Epistolae Matthiae Corvini regis Hungariae ad pontifices, imperatores, reges, principes, aliosque viros illustres datae (Košice: Academia Societatis lesu, 1743), docs. 1 and 2, 1-3. In his recent work, Alexandru Simon pointed to errors in both older and current, primarily Hungarian scholarship, with respect to the chronology of negotiations and truces in the 1480s. Although Simon competently questions both the chronology and the existence of a definitive truce, as well as sheds light on new sources and unresolved questions related to the issue, he acknowledges that the probability that the two sides achieved treaties during the decade is high. His contributions to the question are closely related to the issues of chronology discussed briefly below in note 71. See: Simon, "Truces and Negotiations between Bayezid II and Matthias Corvinus in the Context of the Hunyadi-Habsburg Conflict (1482-1484)," Revista Arhivelor 86 (2009): 107-14, and the bibliography listed there. Also: Richárd Horváth, "Voievodul transilvănean Ştefan Bátori şi frontul turcesc între 1479 şi pacea din anul 1483" [The Voivode of Transylvania Stephen Bátori and Turkish Front between 1479 and Peace of 1483], Banatica 24 (2014): 289-308.

64 Claude Raffestin, "Elements for a Theory of the Frontier," Diogenes 34 (1986): 1-18, Also in Claude Raffestin, "Elementi per una teoria della frontiera," in La frontiera da stato a nazione. Il caso Piemonte, ed. Carlo Ossola, Claude Raffestin and Mario Ricciardi (Rome: Bulzoni, 1987), 21-37. On Raffestin's work see: Francisco R. Klauser, "Thinking through Territoriality: Introducing Claude Raffestin to Anglophone Sociospatial Theory," Environment and Planning D: Society and Space 30 (2012): 106-20.

65 Edoardo Grendi, "La pratica dei confini: Mioglia contro Sassello, 1715-1745," Quaderni storici n.s. 21/63 (1986): 811-45.

See, especially: Dariusz Kołodziejczyk, Ottoman-Polish Diplomatic Relations (15th-18th Century). An Annotated Edition of 'Ahdnames and Other Documents (Leiden, Boston and Köln: Brill, 2000); Sándor Papp, "Hungary and the Ottoman Empire (From the Beginnings to 1540)," in Fight Against the Turk in Central Europe in the First Half of the $16^{\text {th }}$ Century, ed. István Zombori (Budapest: METEM, 2004), 37-89.

67 Kołodziejczyk, Ottoman-Polish Diplomatic Relations, 57-68. 
the same class, refers to the Hungarian-Ottoman case, we can get a grasp of some elements of definition and, to an extent, demarcation within the Hungarian-Ottoman bordering process.

According to some assumptions, a document of such type might have been appended to the truce of $1444,{ }^{69}$ but both drafts and capitulations from the Hunyadi and Jagiello period do contain notes on the distribution of the territory. While such articles are quite elaborate in the Hungarian version of the agreements from 1503 and $1519,{ }^{70}$ a draft of the Ottoman name from 1488 refers to these issues with a brief note: "The lands, provinces, castles, and fortresses of the said king (i.e. Matthias) should stay as they were. The same goes for provinces, fortresses, and castles in my (i.e. Bayezid II's) land" ${ }^{71}$ It is quite probable that a relatively detailed list of these castles, provinces, and fortresses found its way into the final versions of the truce, as it did in 1503 and 1519. Although a border was not defined explicitly in these documents, it is mentioned and indirectly demarcated by references to specific lands and castles, as well as their appurtenances, surrounding territories, and metae eorundem. ${ }^{72}$ Naturally, this would mean that the boundaries of estates surrounding critical castles figured as political borders. A demarcation on that level would require, however, a far more complex process of bordering than the exchange of oaths and capitulations. Nevertheless, a relatively detailed demarcation of boundaries of estates was not an unknown practice at the time, and the Ottoman negotiations with Venice following the treaty of 1479 show that, at least nominally, the traditional extents of previously defined areas, estates, districts, or larger political territories were respected, or at least it was an expected political and legal practice. For instance, in 1481 the sultan informed the doge of Venice that he was of a strong opinion that Poljica should remain within his domains, since an emin, having conducted an investigation among all those, great and small, who dwelled in Herzegovina, reported that this area had been ruled by the herceg for some sixty years prior to the Ottoman conquest. As all other lands of the herceg were in his hands, or so the sultan believed, even Poljica ought to be included among them. ${ }^{73}$ Assuming such an investigation indeed took place, of which I have no other evidence, it would not have differed much from the process involving perambulations of estates, when, apart from written evidence, the testimonies of neighbours and the local population in general served as the legal authority on matters of boundaries. ${ }^{74}$ No such document referring to

$300-5$.

69 Cf. Kołodziejczyk, Ottoman-Polish Diplomatic Relations, 107; Papp, "Der ungarisch-türkische Friedensvertrag im Jahre 1444," Chronica 1(2001): 67-78.

70 MNL OL DL 30498, 24393; Thallóczy, Codex diplomaticus partium Regno Hungariae adnexarum, vol. 4, Jajca (bánság, vár és város) története (1450-1527) [The history of the (banate, castle, and town) of Jajce ], Oklevelek, doc. 106, 167-70.

71 G. Hazai, "Urkunde des Friedensvertrages zwischen könig Matthias Corvinus und dem türkischen sultan 1488," in Beiträge zur Sprachwissenschaft, Volkskunde und Literaturforschung: Wolfgang Steinitz zum 60. Geburtstag am 28. Februar 1965 dargebracht, eds. Alexander V. Isačenko, Wilhelm Wissmann, Hermann Strobach (Berlin: Akademie, 1065), 143: cf. idem, "A Topkapu Szeráj,," 294-5.

72 See note 70.

73 Bombaci, "Nuovi firmani," 316-8.

74 Innumerable examples, both from Hungary and elsewhere, exist. An interesting case is, for 
Hungary (or Bosnia, or Croatia) from the period has come to us or has yet been discovered. However, a similar process, which I will return to further below, may have occurred in western portions of the Ottoman-Hungarian borderlands, primarily in Bosnia.

The material pertaining to the period between the early 1460 s and 1478 (1482), largely authored by various Italian ambassadors, as we have seen, regularly lacks information on the border itself and is mostly concerned with various demands or offers presented by the two sides. However, already László Fenyvesi, in his abovementioned overview of Hungarian-Ottoman diplomatic relations, briefly hinted at the importance of "economy and trade" in them by referring to Újlaki's Apajócz case. ${ }^{75}$ Regardless of whether the truce was agreed upon in 1468, it was anticipated that a certain middle ground, along the border, would be reserved for trade between the subjects of the two princes, and one such place was the area of Apajócz. The unhindered travel of traders from the sultan's lands ad confinia Regni was also a major part of the truce of $1483,{ }^{76}$ and one of the clauses of the draft from 1488, the longest of all, addresses this issue specifically. According to it, traders from both polities would be free to travel on either side provided they had safe conduct, and any damage sustained within the sultan's domains would be met with punishment in accordance with shari'a law. ${ }^{77}$ They would also pay any customs due, according to the "customs of the lands." The marketplace at Apajócz, described by the king in 1467 as a place where "both peoples" may come to trade freely, was listed in 1498 among the loca tricesimarum under the jurisdiction of Belgrade, along with Šabac (Zaslon), Szávaszentdemeter (Sremska Mitrovica), Rača, Kölpény (today Kupinovo), all of which (including, probably, Poltos) lie on the Sava and are crossing points along the river. $^{78}$ In 1488, furthermore, the sanjak-beys of Smederevo and the captains of Belgrade were granted jurisdiction over safe conduct for the subjects on both sides. ${ }^{79}$

Apart from the draft of the sultan's 'ahdname of 1488, six other documents, all correspondence, published and briefly discussed previously by Tayyib Gökbilgin, Nikola Radojčić, and György Hazai, ${ }^{80}$ dating from c.

instance, the perambulation between the Istrian possessions of the lords of Kožljak and Duino from 1395: Ivan Kukuljević Sakcinski, Acta Croatica (Zagreb: Narodna tiskarnica, 1863), doc. $13,46-7$.

75 See note 35.

76 Kelcz, Epistolae Mathiae Corvini, doc. 2, 2-3.

77 Hazai, "Urkunde des Friedensvertrages," 144.

78 István Werbőczy, Decretum generale inclyti Regni Hungariae partiumque eidem annexarum (Buda, 1844), 286. The decree of 1498 was recently also published in: Péter Banyó and Martyn Rady, Decreta regni mediaevales Hungariae, vol. 4 (Idyllwild and Budapest: Charles SchlacksCEU, 2012), 84-137. Although this edition contains a translation of the decree's text into English, I would strongly advise care when dealing with it.

Hazai, "A Topkapu Szeráj," 294-5.

80 Tayyib Gökbilgin, “Korvin Mathias (Mátyás) ın Bayezit II.e Mektupları Tercümeleri ve 1503 (909) Osmanlı-Macar Muahedesinin Türkçe Metni" [Translation of letters of Matthias Corvinus and Bayezid II, and the text of the Ottoman-Hungarian treaty of 1503 (909)], Belleten 22 (1958): 369-90; cf. idem, "Macar kralı Korvin Mathias' dan Bayazıt II. ye gelen mektup" [Matthias's Corvinus letters to Bayezid II], Bilgi 82 (1954): 1-3; Hazai, "A Topkapu Szeráj"; idem; "Eine türkische Urkunde zur Geschichte der ungarisch-türkischen Beziehungen im XV. Jh.," Ural-Altaische Jahrbücher 36 (1964): 336-9; idem, "Zur Rolle des Serbischen im Verkehr des 
1482/1483 and 1486/1487, are the most detailed and explicit sources on the border negotiation, its shape, and role. Three documents, authored by Stephen Bátori, the court judge and the voivode of Transylvania at the time, and Vuk Branković, a scion of the Serbian Brankovic dynasty and at the time the titular despot of Serbia, date from 1482/early 1483, ${ }^{81}$ while another set of three documents, compiled in the chanceries of the king and the sultan, date from a later period, probably 1486/1487, before the conclusion of the truce of $1488 .{ }^{82}$ Most (probably all originally) written in Cyrillic script and subsequently translated and transliterated for the use in Istanbul or at Matthias' court, these documents reveal the issues that went along with the 'normalization' of relations and the definition of the role of the border and its administrative character.

Bátori's letter was already briefly discussed and does not offer much more on the issue. Brankovićs letters, however, do. Firstly, one reveals that during the talks between Matthias and Bayezid, the newly enthroned sultan, who found himself in some trouble primarily due to the ambitions of his brother Djem, it was even considered that a system practiced at the times of kings Sigismund, those from the Habsburg house, the first Jagiello, and the early years of Matthias' reign be put back into force. Specifically, the reestablishment of a buffer zone in the form of a vassal Serbian state, "as it was in the times of our [i.e. Vuk's] forefathers," was taken into consideration by the Sublime Porte. ${ }^{83}$ This solution, obviously, was not put into force. Another of Vuk's letters shows that Matthias demanded complete peace at the frontier during negotiations, i.e. that the sultan should have halted the construction of several fortresses "on a hill at the Danube" across his lands, which Matthias had to counter by sending troops on the opposite, Hungarian bank. ${ }^{84}$ The despot further informed the sultan that the king suggested a certain demilitarized zone be established before envoys embark on their travels. ${ }^{85}$ Interestingly, and quite disproportionately, this zone would be demarcated by Niš and Kruševac on the Ottoman, and by Szeged and Timișoara on the Hungarian side, with an addition that the king's troops would certainly not go beyond Futog and Slankamen (both of which are right on the Danube, but further inland from Belgrade), which was supposed to be enforced throughout the duration of negotiations.

Osmanischen Reiches mit Osteuropa im 15.-16. Jahrhundert," Ural-Altaische Jahrbücher 48 (1976): 82-8; idem, "Eine Urkunde der ungarisch-türkischen Friedensverhandlungen in der Zeit von Matthias Corvinus und Bāyezīd II," Rocznik Orientalistyczny 38 (1976), 155-60; idem, "Ein Bericht über die Lage des ungarisch-türkischen Grenzgebiets in den letzten Jahren der Regierungszeit von Matthias Corvinus," Studia Slavica Academiae Scientiarum Hungaricae 25 (1979): 183-7; Radojević, "Pet pisama," 343-67. Cf. Ljubomir Stojanović, Stare srpske povelje i pisma vol. 1. Dubrovnik i susedi njegovi, pt. 2 [Old Serbian charters and letters. Dubrovnik and its neighbours] (Belgrade-Sremski Karlovci: Srpska manastirska štamparija, 1934), docs. 1 and 2, 487-9.

81 Radojević, "Pet pisama," 353-4; 362-3; Stojanović, Stare srpske povelje i pisma, docs. 1 and 2, 487-9.

82 Gökbilgin, "Korvin Mathias," 379-81; Hazai, "Eine türkische Urkunde," 337-9; Radojević, "Pet pisama," 363-6.

83 Radojević, "Pet pisama," 353-4.

84 Stojanović, Stare srpske povelje i pisma, doc. 2, 488-9.

85 Ibid. 
Among other things discussed, the letters by Matthias and Bayezid, seemingly sent in succession during the summer of 1487, focus on the wrongdoings of the local frontier lords, both Ottoman and Hungarian, deeds that went against the stipulations of the two rulers.86 In June 1487, King Matthias pointed at least two times to the bad behaviour of the sanjak-bey of Bosnia who pillaged the Hungarian-controlled areas of Bosnia as well as Croatia, a man who, according to the king, swore to avenge his defeat against Hungarian troops near Knin regardless of the sultan's commands. 87 While praising the sanjak-bey of Smederevo, a "peace-loving man," and admitting wrongdoings committed by his own captains, the king repeats a request for an establishment of a sort of legal institution, comprised of representatives from both sides, who would control the violence at the border and sanction all illegal activity. That these requests and accusations by the king were constant is revealed in all three letters, and most vividly by the king's own words:

da smo se ûre toliko krat vašoi visoti za škode i za pline koje su se od one strane našim učinile tužili da ûr znaemo da smo tužbom dodijali vašoi visoti i ûr vekje sramujemo se poniki put tužiti vašoi visoti [...] neka zna vaša visôta da dokle se oni ne izvrže ni vaša visôta o(d) našeh tužab se može izbaviti." [We complained so many times to your highness about the damage and plundering brought upon our (people) that we know that we annoy your highness, and we even feel ashamed to complain to your highness sometimes [...] Your highness should know that until (disobedient frontier lords, the worst among whom is the bey of Bosnia) are removed, your highness will not be able to escape our complaints.

It is not completely clear from the king's letters whether this joint commission was agreed upon in the truce of 1483, although it may be assumed on the basis of the letters' wording (the king's claim that such requests were made before, apparently without concrete results). However, Bayezid's response to the king's complaints is far more suggestive. While stating that although he sent an emin as the Ottoman representative at this "court," the Hungarian side had not responded by sending its own man, the sultan claims that "your Majesty ought to remember that, when you informed my court on the matter (i.e. the unruly border captains), an honest man and a reliable emin was dispatched from my court, because we strongly adhered to the friendship and the treaty" (that is ahd: 'ahdum ve dostligum). ${ }^{88}$ This phrase strongly suggests that an introduction of such an institution had earlier been agreed upon, quite probably in the truce of 1483, if not before. It figures again in the draft of the 'ahdname of 1488, where a clause is included which states that the sultan would install a "reliable man" at Smederevo, while the king's should be stationed at Belgrade. Their joint task would be to control violence, prevent vengeance, oversee the compensation of victims, and punish perpetrators, primarily in deeds against traders and other people crossing the border. ${ }^{89}$

\footnotetext{
Gökbilgin, "Korvin Mathias," 379-81; Hazai, "Eine türkische Urkunde," 337-9; Radojević, "Pet pisama," 363-6.

87 Gökbilgin, "Korvin Mathias," 380-1; Radojević, "Pet pisama," 363-6.

88 Hazai, "Eine türkische Urkunde," 337.

89 Hazai, "Urkunde des Friedensvertrages," 144.
} 
While the draft of 1488 lists the sanjak-beys stationed at the frontier and Hungarian "border bans" as authorities who would issue letters of safe conduct, these two judges were not specified and were to be elected by the king and the sultan specifically for the occasion. While the sultan mentions an emin as his representative, in a letter from 1487, preceding the renewal of the truce, the king states that he had entrusted his kincstartó (i.e. treasurer) with the task of finding murderers of an Ottoman subject killed on Hungarian soil, as well as to locate his belongings and compensate the damage. ${ }^{90}$ At the time the king's chief treasurer was Urban Nagylucsei, the incumbent (elected) bishop of Eger, and the judge at the palatine's court. ${ }^{11}$ Whether his role in the cases presented in praesentia palatinali had anything to with his appointment at the border is unknown, and no evidence points to this possibility.

It is noteworthy that most of the institutional arrangements are focused on the border around the Danube although, according to the king's complaints, the areas of Bosnia and Croatia were the most troublesome at the time. Indeed, the "frontier beys" and the "border bans" are not specified in any of these documents and, as far as we know, this probably also implied the sanjak-bey of Bosnia and the bans of Bosnia, Croatia and Slavonia, but the judges in control of the border were to be stationed at Belgrade and Smederevo, not Jajce and Vrhbosna. As mentioned earlier, the area of Bosnia was a tricky case, as, in words of Tubero, "est regio Illyrici inter Valdanum, quem fluuium Hunnam uulgo uocant, et Drinum amnem sita, partim Hungaricae, partim Turcaice ditionis, nunc Bossinae regnum nuncupatur." ${ }^{\prime 92}$ The earlier polity of the Kingdom of Bosnia was territorially separated in Hungarian and Ottoman sections and both states claimed their rights on the whole territory (at least idealised) of the old kingdom. In 1468 Mehmed II reportedly claimed that Jajce (with the rest of Bosnia) should be given to him "since Jajce belongs to the Kingdom of Bosnia, and not the Kingdom of Hungary [...] and since he [i.e. the sultan] removed its king in this last war." ${ }^{\text {93 }}$ On the other hand, both Újlaki and Branković "ardent desiderio recuperandorum statuum suorum. ${ }^{194}$ Neither side, however, could in practice claim anything similar to the sultan's claims about Herzegovina mentioned earlier. On the other hand, the situation further to the east, at the place where the Hungarian partes inferiores, under the command of Paul Kinizsi throughout the 1480s, and the sanjak of Smederevo bordered, was far more clear cut. The geographical characteristics of the area, i.e. the Danube, facilitated the maintenance of a linear border, a borderthat had previously separated Hungary from the Serbian despotate. It is no coincidence, then, that arrangements could have been made far easier at that portion of the frontier, where the local captains oversaw a clearly demarcated territory

\footnotetext{
90 Gökbilgin, "Korvin Mathias," 379-80.

91 MNL OL DL 69513: cf. Magyarország világi archontológiája 1458-1526 vol. I - Föpapok és bárók [Hungarian lay archontology 1458-1490 - Prelates and barons], eds. Norbert Tóth et al. (Budapest: MTA, 2016), 81, 130.

92 Ludovicus Cerva Tubero, Comentarii de temporibus suis, eds. Vlado Rezar et al. (Zagreb: Hrvatski institut za povijest, 2001), 23.

93 Nagy, Nyáry, Magyar diplomacziai emlékek II, doc. 47, 79-80.

94 Janko Šafárik, Acta archivi Veneti spectantia ad historiam Serborum et reliquorum Slavorum meridionalium, vol. 2 (Belgrade, 1860), doc. 514, 545.
} 
and Ottoman merchants travelled to specifically designated markets located along the banks of the Danube and Sava. That both polities invested an effort in maintaining such a linear boundary and in funnelling the flow of both peoples and goods in specific porous points along it is further suggested by the already mentioned Ottoman request for the demolition of Šabac, as well as other smaller fortresses south of the Danube and Sava, Hungarian "exclaves" in otherwise Ottoman territory. ${ }^{95}$ These porous points along the rivers, primarily the Danube, in essence legally defined border-crossings, figured in Hungarian-Ottoman treaties at least since the 1440s and were thus merely reintroduced during Matthias' reign. ${ }^{96}$ Both porous points, the free access of merchants to either territory, similar terms of trade, as well as authorities tasked with the protection of their lives and goods and the control of violence along the border were present in other Muslim-Christian or Ottoman-Polish/Venetian, later Austrian treaties, as is best exemplified by Ottoman-Polish treaties ${ }^{97}$ and the situation along the Iberian frontiers. There collaborative institutions, judicial in nature and aimed at controlling the cross-border flow and violence, gained particular importance during the fourteenth and fifteenth centuries, as was recently highlighted by José Enrique López de Coca Castañer. ${ }^{98}$

Finally, the authorities which performed the border of the kingdom in their capacities to either influence its definition or maintain it were, as mentioned in the discussion above, despot Vuk, Stephen Bátori, Nicholas Újlaki, Peter Dóci, as well as a myriad of other frontier captains (such as Kinizsi), all of whom occupied offices at the border (Bosnian castellanies, the voivodship of Transylvania, the banate of Macsó and the Bosnian kingship, and the banate of Bosnia, respectively), and, certainly, the king. On the other side there were the sanjak-beys of Bosnia and Smederevo along with the sultan. The situation on the Hungarian side, then, corroborates king Matthias' words from his 1465 letter to his allies in Venice, where he states that constant pledges for a truce along the border came largely ex baronibus nostris, officia Turcis finitima tenentibus. ${ }^{99}$ That Matthias' royal council as well as the kingdom's general diet had a say in the negotiating process and had an influence on the terms of bordering and the border's maintenance

95 See above, note 56. Also: József Csermely, "A Szendrő közelében épített magyar erődök szerepe Hunyadi Mátyás törökellenes védelmi rendszerében" [The role of Hungarian fortifications near Smederevo in Matthias Hunyadi's anti-Turkish defence system], Hadtörténelmi Közlemények 124 (2011): 845-63.

96 See:MNL OL Diplomatikai Levéltár 14259(negotiations from 1449);Zsolt Simon, Magyarország és az Oszmán birodalom közötti kereskedelmi kapcsolatok a 16. század elejen. A baricsi es kölpényi harmincadok forgalma [Trade relations between Hungary and the Ottoman Empire at the beginning of the sixteenth century. The trade at the thirtieth customs posts of Barics and Kölpényi], PhD diss., ELTE, 2007), 6-60.

97 Cf. Viorel Panaite, "Trade and Merchants in the $16^{\text {th }}$ Century Ottoman-Polish Treaties," Revue des Études Sud-Est Européennes 32(1994): 259-76.

98 José Enrique López de Coca Castañer, "Los jueces de las querellas" [The judges of complaints ], Edad Media: revista de historia 11 (2010): 173-201; idem, "La frontière avec le royaume de Grenade: territoire et ligne de demarcation (XIVe et XVe siècle)," in Entre Islam et Chrétienté: La territorialisation des frontières, $X l^{e}-X V l^{e}$ siècle, eds. Stéphane Boissellier and Isabel Cristina Ferreira Fernandes (Rennes: Presses Universitaires de Rennes, 2015), 171-90. Fraknói, Mátyás király levelei I, doc. 59, 77-9. 
is testified by a number of sources. Maybe most telling among them are several letters from 1473, 1486/1487, and 1488. In 1473, the king sent a letter to landowners and the nobility of the county of Körös in Slavonia (and probably throughout the kingdom) after his emissaries had returned from Ottoman and Polish courts. ${ }^{100}$ Having received the reports on negotiation, the king, under the influence of the council and the decision of the prelati et barones regni, summoned the kingdom's diet to discuss further steps. A report of the Ottoman ambassador Hācï Zaganos, who in 1488 visited the king in order to confirm the treaty, further points to the council's and the diet's influence in international relations. Zaganos states that, while negotiating with French ambassadors, the king told them "to stay until after the Easter of the unbelievers, when all Hungarian lords would gather in Buda and the ambassadors would only receive their answer at this assembly. ${ }^{\prime 101}$ Finally, we have a detailed description of the events at the royal court following the arrival of news of the murder of Dmitar Jakšić, royal emissary dispatched in 1486 by Vuk Kulučegović, an Ottoman spy apparently employed at Matthias' court, according to Hazai's assumptions, possibly even in the royal chancery, i.e. its "Cyrillic section." ${ }^{102}$ Vuk's report speaks of a discussion among the king and his lords about the appropriate response to this crime, while Vuk identifies these lords as "beys." Regardless of whether this refers to the barons of the kingdom, members of the royal council, or, less likely, the members of the king's intimate entourage, i.e. his aula, it is clear even from these four cases that both lords close to the border and those close to the royal court influenced the negotiations and the characteristics of the border.

\section{Final Remarks}

Presently available evidence, as shown above, largely belongs to a group of epistolary materials containing information on negotiations, rather than on specific treaties defining or demarcating, let alone delimiting the border between the lands of the kingdom and those of the empire. At this point, we have no elaborate documents which would resemble terminationes of the Mediterranean of communes, no demarcations which would be as detailed as perambulations of estates within the Kingdom of Hungary, no agreements as meticulous as bordering on local levels, and no delimitations as punctilious as the work of count Luigi Marsigli. ${ }^{103}$ This would all suggest that more specified institutional forms of bordering, both documentary and archontological, on such a grand level were not yet achieved within the political discourse and practice of the Kingdom of Hungary, and would fit well into the claim made by Hans-Jürgen Karp in 1972 that the Grenzsaum, rather

\footnotetext{
$100 \quad$ MNL OL DF 268093.

101 Hazai, "Eine Urkunde der ungarisch-türkischen Friedensverhandlungen," 159.

102 Hazai, "Zur Rolle des Serbischen," 86-8.

103 See: Giampaolo Francesconi and Francesco Salvestrini, "La scrittura del confine nell'Italia comunale. Modelli e funzioni," in Frontiers in the Middle Ages, ed. Outi Merisalo (Louvain-laNeuve: Fédération Internationale des Instituts d'Études Médiévales, 2006), 197-221; János M. Bak et al., eds., The Laws of the Medieval Kingdom of Hungary, vol. 5: The Customary Law of the Renowned Kingdom of Hungary: A Work in Three Parts Rendered by Stephen Werböczy (The Tripartitum) (Idyllwild and Budapest: Charles Schlacks and Department of Medieval Studies at CEU, 2005), s.v. boundaries, 443.
} 
than Grenzlinie, dominated European medieval bordering, both on lower and higher levels, until well into the twelfth century, while the border-line took over only gradually. ${ }^{104}$ However, confinia finds its place even in sources discussed above, and it would certainly be improbable (if not impossible) that the two sides negotiated, say, merchants' travels and rights at the confines of two realms if these confines were left without any definition, and linear at that. The lack of detailed sources requires an application of concepts and theoretical backdrops such as that of Thomas Nail, which proved most valuable and allowed us to look beyond the obscurity of materials at hand. Its application showed that junctions or porous points which filtered the cross-border flow and allowed for the passage of goods while, in theory, blocking any other flow along the borders would thus have to have at least a conceptualized linearity along the southern rivers. The complex situation within the Bosnian borderland requires further research, especially in the field of geopolitical conflict-resolution methods, as well as on political and administrative integration of the borderland into the governing systems of adjacent polities, the Kingdom of Hungary and the Ottoman Empire.

\section{SOURCES}

1. Bachmann, Adolf. Fontes rerum Austriacarum. Diplomataria et Acta. Vol. 46. Urkundliche Nachträge zur österreichisch-deutschen Geschichte im Zeitalter Kaiser Friedrich III. Vienna: F. Tempsky-Kaiserliche Akademie der Wissenschaften, 1892.

2. Bak, János M., Péter Banyó and Martyn Rady, eds. with an introductory study by László Péter. The Laws of the Medieval Kingdom of Hungary. Vol. 5: The Customary Law of the Renowned Kingdom of Hungary: A Work in Three Parts Rendered by Stephen Werböczy (The Tripartitum). Idyllwild and Budapest: Charles Schlacks and the Department of Medieval Studies at CEU, 2005.

3. Banyó, Péter, Martyn Rady. Decreta regni mediaevales Hungariae. Vol. 4. Idyllwild-Budapest: Charles Schlacks-CEU, 2012.

4. Bombaci, Alessio. "Nuovi firmani greci di Maometto II." Byzantinische Zeitschrift 47 (1954): 298-319.

5. Cerva Tubero, Ludovicus. Comentarii de temporibus suis. Edited by Vlado Rezar. Zagreb: Hrvatski institut za povijest, 2001.

6. Državni arhiv u Dubrovniku [State archives in Dubrovnik]. Acta Consilii Rogatorum XXI.

7. Fraknói, Vilmos. Mátyás király levelei. Külügyi osztály [The letters of king Matthias. Foreign affairs ]. Vol. I. Budapest: MTA, 1893.

8. Gelchich, József. Diplomatarium relationum Reipublicae Ragusanae cum Regno Hungariae. Budapest: MTA, 1877.

9. Gökbilgin, Tayyib. "Macar kralı Korvin Mathias' dan Bayazıt II. ye gelen mektup" [Matthias's Corvinus letters to Bayezid II]. Bilgi 82 (1954): 1-3.

104 Hans-Jürgen Karp, Grenzen in Ostmitteleuropa während des Mittelalters (Cologne-Vienna: Böhlau Verlag, 1972); also Reinhard Schneider, "Lineare Grenzen - Vom frühen bis zum späten Mittelalter," in Grenzen und Grenzregionen, ed. Wolfgang Haubrisch, Reinhard Schneider (Saarbrücken: SDV, 1993), 51-68. 
10. Gökbilgin, Tayyib. "Korvin Mathias (Mátyás) In Bayezit II.e Mektupları Tercümeleri ve 1503 (909) Osmanlı-Macar Muahedesinin Türkçe Metni" [Translation of letters of Matthias Corvinus and Bayezid II, and the text of the Ottoman-Hungarian treaty of 1503 (909)]. Belleten 22 (1958): 369-90.

11. Hazai, György. "A Topkapu Szeráj Múzeum levéltárának magyar vonatkozású török iratai" [Turkish documents in the archives of the Topkapı Palace Museum with relevance to Hungary]. Levéltári Közlemények 26 (1955): 286-295.

12. Hazai, György. "Urkunde des Friedensvertrages zwischen könig Matthias Corvinus und dem türkischen sultan 1488." In Beiträge zur Sprachwissenschaft, Volkskunde und Literaturforschung: Wolfgang Steinitz zum 60. Geburtstag am 28. Februar 1965 dargebracht. Edited by Alexander V. Isačenko, Wilhelm Wissmann and Hermann Strobach, 141145. Berlin: Akademie, 1965.

13. Hazai. "Eine türkische Urkunde zur Geschichte der ungarisch- türkischen Beziehungen im XV. Jh.," Ural-Altaische Jahrbücher 36 (1964): 336-9.

14. Hazai, György. "Zur Rolle des Serbischen im Verkehr des Osmanischen Reiches mit Osteuropa im 15.-16. Jahrhundert." Ural-Altaische Jahrbücher 48 (1976): 82-8.

15. Hazai, György. "Eine Urkunde der ungarisch-türkischen Friedensverhandlungen in der Zeit von Matthias Corvinus und Bāyezīd II." Rocznik Orientalistyczny 38 (1976): 155-60.

16. Hazai, György. "Ein Bericht über die Lage des ungarisch-türkischen Grenzgebiets in den letzten Jahren der Regierungszeit von Matthias Corvinus." Studia Slavica Academiae Scientiarum Hungaricae 25 (1979): 183-7.

17. Iorga, Nicolae. Notes et extraits pour servir à l'histoire des Croisades au XVe siècle. Vol. IV. Bucharest: Academia Română, 1915.

18. Kelcz, Imre. Epistolae Matthiae Corvini regis Hungariae ad pontifices, imperatores, reges, principes, aliosque viros illustres datae. Košice: Academia Societatis lesu, 1743.

19. Kukuljević Sakcinski, Ivan. Acta Croatica. Zagreb: Narodna tiskarnica, 1863.

20. Ljubić, Šime. Monumenta spectantia historiam Slavorum meridionalium. Vol. XXII. Listine o odnošajih između Južnoga Slavenstva i Mletačke Republike [Documents on the relations between the South Slavs and the Republic of Venice]. Vol. X. Zagreb: JAZU, 1891.

21. Magyar Nemzeti Levéltár, Országos Levéltára [Hungarian national archives, State archives]. Diplomatikai Fényképgyüjtemény [Diplomatic photo-collection].

22. Ménage, Victor Louis. "Seven Ottoman Documents from the Reign of Mehemmed II." In Documents from Islamic Chanceries: First Series. Edited by Samuel M. Stern, 81-118. Cambridge, MA: Harvard University Press, 1965, .

23. Nagy, Iván, Albert Nyáry. Monumenta Hungariae historica, vol. IV. Acta extera: Magyar diplomacziai emlékek Mátyás király korából [Hungarian diplomatic memories from the period of king Matthias], vols. I-II. Budapest: MTA, 1875-1877. 
24. Radojčić, Nikola. "Pet pisama s kraja XV. veka" (prijevod na engl). [Five letters from the end of the fifteenth century]. Južnoslovenski filolog 20 (1953-1954): 343-367.

25. Salihović, Davor. "Nonnulla documenta pertinentia ad Nicolaum de Wylak, regem ultimum Regni Bosnae." Scrinia Slavonica 17(2017): 403-418.

26. Stojanović, Ljubomir. Stare srpske povelje i pisma. Vol. 1. Dubrovnik i susedi njegovi. Pt. 2 [Old Serbian charters and letters. Dubrovnik and its neighbours]. Belgrade and Sremski Karlovci: Srpska manastirska štamparija, 1934.

27. Šafárik, Janko. Acta archivi Veneti spectantia ad historiam Serborum et reliquorum Slavorum meridionalium. Vol. 2. Belgrade: 1860.

28. Thallóczy, Lajos, Antal Áldásy. Monumenta Hungariae historica. Vol. XXIII. Codex diplomaticus partium Regno Hungariae adnexarum. Vol. II. Magyarország és Szerbia közti összeköttetések oklevéltára 1198-1526 [Documents on Hungarian-Serbian relations]. Budapest: MTA, 1907.

29. Thallóczy, Lajos. "Frammenti relativi alla storia dei paesi situati all'Adria." Archeografo Triestino ser. 3, 7(1914): 47-281.

30. Thallóczy, Lajos. Codex diplomaticus partium Regno Hungariae adnexarum. Vol. 4. Jajca (bánság, vár és város) története (1450-1527)[The history of the (banate, castle, and town) of Jajce]. Oklevelek. Budapest: MTA, 1915.

31. Thúry, József. Török történetírók [Turkish historians] vol. I. Budapest: MTA, 1893.

32. Wadding, Luke. Annales Minorum seu Trium Ordinum a S. Francisco institutorum. Vol. XIV. Rome: Rocco Bernabò, 1735.

33. Werbőczy, István. Decretum generale inclyti Regni Hungariae partiumque eidem annexarum. Buda, 1844.

\section{BIBLIOGRAPHY}

1. Atanasovski, Veljan. Pad Hercegovine [The fall of Hercegovina]. Belgrade: Narodna knjiga-Istorijski institut u Beogradu, 1979.

2. [Babinger, Franz] Babinger, Franc. Mehmed Osvajač u njegovo doba [Mehmed the Conqueror and his time]. Belgrade: Algoritam, 2010.

3. Bánlaky, József. "Az 1463. évi délvidéki és boszniai hadjárat. Az ugyanezen évi tolnai országgyülés határozatai" [Southern and Bosnian campaign of 1463. Decisions of the Diet of Tolna in the same year ]; "Az 1464. évi boszniai hadjárat" [The campaign in Bosnia of 1464]. In idem, A magyar nemzet hadtörténelme. Accessed January 7, 2018, https://www.arcanum.hu/hu/ online-kiadvanyok/Banlaky-banlaky-jozsef-a-magyar-nemzet-hadtortenelme-2/

4. Berend, Nora. "L'évolution de la territorialisation dans le défense de la Hongrie du XIII au XVI siècle." In Entre Islam et Chrétienté: La territorialisation des frontières, $X l^{e}-X V l^{e}$ siècle. Edited by Stéphane Boissellier and Isabel Cristina Ferreira Fernandes, 217-32. Rennes: Presses Universitaires de Rennes, 2015.

5. Bojanić, Dušanka. "Dve godine istorije Bosanskog krajišta (1479. i 1480.) prema Ibn-Kemalu" [Two years in the history of the Bosnian march (1479 
and 1480) according to Ibn-Kemal]. Prilozi za orijentalnu filologiju 13-15 (1964): 33-50.

6. Borosy, András. "Határörség és határörök az Árpádok korában" [Border protection and border guards in the Árpád period]. Hadtörténelmi Közlemények 24 (1977): 543-57.

7. Ćirković, Sima. "Srednji vek" [The medieval period]. In Šabac u prošlosti [The history of Šabac]. Edited by Stanoje Filipović (Šabac: Istorijski arhiv, 1970), 93-101.

8. Csánki, Dezső. "Szabács megvétele," [The fall of Šabac]. Hadtörténelmi Közleméynek 1(1888): 355-88.

9. Csánki, Dezső. Magyarország történelmi földrajza a Hunyadiak korában [Hungarian historical geography in the Hunyadi period]. Vol. Il. Budapest: MTA, 1894.

10. Csermely, József. "A Szendrő közelében épített magyar erődök szerepe Hunyadi Mátyás törökellenes védelmi rendszerében" [The role of Hungarian fortifications near Smederevo in Matthias Hunyadi's anti-Turkish defence system ]. Hadtörténelmi Közlemények 124 (2011): 845-863.

11. de Coca Castañer, José Enrique López. "Los jueces de las querellas" [The judges of complaints]. Edad Media: revista de historia 11 (2010): 173-201.

12. de Coca Castañer, José Enrique López. "La frontière avec le royaume de Grenade: territoire et ligne de demarcation (XIVe et XVe siècle)." In Entre Islam et Chrétienté: La territorialisation des frontières, Xle - XVIe siècle. Edited by Stéphane Boissellier and Isabel Cristina Ferreira Fernandes, 171-190. Rennes: Presses Universitaires de Rennes, 2015,

13. Deér, József. "Zsigmond király honvédelmi politikája" [King Sigismund's defensive policy]. Hadtörténelmi Közlemények 37 (1936), 1-57, 169-202.

14. von Engel, Johann Christian. Geschichte des ungrischen Reichs. Vol. III/l. Wien: Friedrich Volke, 1834.

15. Engel, Pál. The Realm of St Stephen: A History of Medieval Hungary, 8951526. London and New York: I. B. Tauris, 2001.

16. Fenyvesi, László. "Magyar-török diplomáciai kapcsolatok Mátyás király haláláig." [Hungarian-Turkish diplomatic relations until the death of king Matthias ]. Hadtörténelmi Közlemények 103 (1990): 74-99.

17. Filipović, Emir. "Minor est Turchorum potentia, quam fama feratur... Contributions to the History of Bosnia in the Second Half of 1463." In Pad Bosanskog kraljevstva 1464. godine. Edited by Neven Isailović 2015, 195226.

18. Fraknói, Vilmos. "Mátyás király magyar diplomatái" [King Matthias's Hungarian diplomats ]. Századok 32 (1898): 1-14, 97-112, 385-404, 481-9, 76981, 865-75; Századok 33 (1899): 1-8, 291-309, 389-410; 773-87, 869-78.

19. Francesconi, Giampaolo, Francesco Salvestrini. "La scrittura del confine nell'Italia comunale. Modelli e funzioni." In Frontiers in the Middle Ages. Edited by Outi Merisalo, 197-221. Louvain-la-Neuve: Fédération Internationale des Instituts d'Études Médiévales, 2006.

20. Göckenjan, Hansgerd. Hilfsvölker und Grenzwächter im mittelalterlichen Ungarn. Wiesbaden: Franz Steiner, 1972.

21. Grendi, Edoardo. "La pratica dei confini: Mioglia contro Sassello, 17151745." Quaderni storici n.s. 21/63 (1986): 811-45. 
22. Horváth, Richárd. "Voievodul transilvănean Ştefan Bátori şi frontul turcesc între 1479 şi pacea din anul 1483" [The Voivode of Transylvania Stephen Bátori and Turkish Front between 1479 and Peace of 1483]. Banatica 24 (2014): 289-308.

23. van Houtum, Henk. "An Overview of European Geographical Research on Borders and Border Regions," Journal of Borderlands Studies 15 (2000): 57-83.

24. Isailović, Neven. "Living by the Border: South Slavic Marcher Lords in the Late Medieval Balkans (13 $13^{\text {th }}-15^{\text {th }}$ Centuries)." Banatica 26 (2016): 105-17.

25. Ivić, Aleksa. Istorija Srba u Vojvodini od najstarijih vremena do osnivanja ptosko-pomoriške granice (1703) [ History of Serbs in Vojvodina from the earliest times to the establishment of Potisje-Pomorišje border (1703)]. Novi Sad: Matica srpska, 1929.

26. Janković, Aleksandar. "Između osmanskog i ugarskog krajišta: osmanskozaposedanje Podrinja i ugarska opsada Zvornika 1464. godine" [Between the Ottoman and Hungarian march: The Ottoman capture of Podrinje and the Hungarian siege of Zvornik in 1464]. In Pad Bosanskogkraljevstva1463.godine[Thefall of theKingdomofBosniain1463]. Edited by Neven Isailović, 227-57. Belgrade, Sarajevo and Banja Luka: Istorijski institut Beograd, Filozofski fakultet u Sarajevu and Filozofski fakultet u Banjoj Luci, 2015.

27. Jug, Stanko. "Turški napadi na Kranjsko in Primorsko do prve tretjine 16. stoletja" [Turkish attacks on Carniola and Primorska until the first third of the $16^{\text {th }}$ century]. Glasnik Muzejskega društva za Slovenijo 24 (1943): 1-61.

28. Kalić-Mijušković, Jovanka. Beograd u srednjem veku [Belgrade in the middle ages]. Belgrade: Srpska književna zadruga, 1967.

29. Kalić-Mijušković, Jovanka, ed. Istorija srpskog naroda. Vol 2: Doba borbi za očuvanje i obnovu države (1371-1537) [History of the Serbian nation, Vol 2: The Period of struggle for the preservation and restoration of the state (1371-1537)]. Belgrade: Srpska književna zadruga, 1982

30. Karp, Hans-Jürgen. Grenzen in Ostmitteleuropa während des Mittelalters. Cologne-Vienna: Böhlau Verlag, 1972.

31. Klauser, Francisco R. "Thinking through Territoriality: Introducing Claude Raffestin to Anglophone Sociospatial Theory." Environment and Planning D: Society and Space 30 (2012): 106-20.

32. Kołodziejczyk, Dariusz. Ottoman-Polish Diplomatic Relations (15th-18th Century). An Annotated Edition of 'Ahdnames and Other Documents. Leiden, Boston and Cologne: Brill, 2000.

33. Kristó, Gyula, Ferenc Makk, László Szegfü. "Szempontok és adatok a korai magyar határvédelem kérdéséhez" [Views and data on the issue of early Hungarian border defence]. Hadtörténelmi Közlemények 20 (1973): 639-58.

34. Kubinyi, András. "Magyarország déli határvárai a középkor végén." Várak a későközépkorban - Die Burgen im Spätmittelalter. Castrum Bene 2 (1990): 65-76.

35. Kubinyi, András. "Die südlichen Grenzfestungen Ungarns am Ende des Mittelalters." In Matthias Corvinus: Die Regierung eines Königreichs in Ostmitteleuropa 1458-1490. Edited by András Kubinyi, 188-201. Budapest: Herne, 1999. 
36. Kubinyi, András. Nándorfehérvártól Mohácsig - A Mátyás és a Jagelló-kor hadtörténete [From Belgrade to Mohács - War history of Matthias's and Jagiellonian period]. Budapest: Argumentum, 2007.

37. Kubinyi, András. Matthias Rex (Budapest: Balassi kiadó, 2008).

38. Minorsky, Vladimir, Clifford E. Bosworth, "Uzun Hasan." In Encyclopaedia of Islam, $2^{\text {nd }}$ ed.

39. Mitrović, Katarina. "Vuk Grgurević između Mehmeda II. i Matije Korvina (1458-1465)" [Vuk Grgurević between Mehmed II and Matthias Corvinus (1458-1465)]. Braničevski glasnik 2 (2003): 19-33.

40. Mitrović, Katarina. "Pet Pisama despota Vuka Grgurevića" [Five letters by Despot Vuk Grgurević ]. Braničevski glasnik 3-4 (2004-2005): 63-83.

41. Nail, Thomas. Theory of the Border. Oxford: Oxford University Press, 2016.

42. Pálosfalvi, Tamás. From Nicopolis to Móhacs: A History of Ottoman-Hungarian Warfare, 1389-1526. Leiden and Boston: Brill, 2018.

43. Panaite, Viorel. "Trade and Merchants in the $16^{\text {th }}$ Century Ottoman-Polish Treaties." Revue des Études Sud-Est Européennes 32 (1994): 259-76.

44. Papp, Sándor. "Der ungarisch-türkische Friedensvertrag im Jahre 1444." Chronica 1(2001): 67-78.

45. Papp, Sándor. "Hungary and the Ottoman Empire (From the Beginnings to 1540)." In Fight Against the Turk in Central Europe in the First Half of the 16 ${ }^{\text {th }}$ Century. Edited by István Zombori, 37-89. Budapest: METEM, 2004.

46. Parker, Noel, Nick Vaughan-Williams. "Lines in the Sand? Towards an Agenda for Critical Border Studies." Geopolitics 14 (2009): 582-7.

47. Parker, Noel, Nick Vaughan-Williams. "Critical Border Studies: Broadening and Deepening the Lines in the Sand Agesnda." Geopolitics 17 (2012): 727-33.Raffestin, Claude. "Elements for a Theory of the Frontier." Diogenes 34 (1986): 1-18.

48. Pop, Ioan-Aurel, Alexandru Simon. "The Venetian and Wallachian Roots of the Hungarian-Ottoman Truce of Spring 1468: Notes on Documents from the State Archives of Milan." In Italy and Europe's Eastern Border (12041669). Edited by Alexandru Simon, Julian Mihai Damian and Mihailo Popovic, 283-301. Frankfurt am Main: Peter Lang, 2012.

49. Raffestin, Claude. "Elements for a Theory of the Frontier." Diogenes 34 (1986): 1-18.

50. Raffestin, Claude. "Elementi per una teoria della frontiera." In La frontiera da stato a nazione. II caso Piemonte. Edited by Carlo Ossola, Claude Raffestin and Mario Ricciardi, 21-37. Rome: Bulzoni, 1987.

51. Ratzel, Friedrich. Politische Geographie oder die Geographie der Staaten, des Verkehres und des Krieges. Munich and Berlin: R. Oldenbourg, 1903.

52. Rázsó, Gyula. "Hunyadi Mátyás török politikája." Hadtörténelmi Közlemények 22 (1975): 305-48.

53. Sack, Robert David. Human Territoriality: Its Theory and History. Cambridge: Cambridge University Press, 1986.

54. Salihović, Davor. "An Interesting Episode: Nicholas of Ilok's Kingship in Bosnia 1471-1477." MA Thesis, Central European University, 2016.

55. Schneider, Reinhard. "Lineare Grenzen - Vom frühen bis zum späten Mit telalter." In Grenzen und Grenzregionen. Edited by Wolfgang Haubrisch and Reinhard Schneider, 51-68. Saarbrücken: SDV, 1993. 
56. Simon, Alexandru. "Truces and Negotiations between Bayezid II and Matthias Corvinus in the Context of the Hunyadi-Habsburg Conflict (14821484)." Revista Arhivelor 86 (2009): 107-114.

57. Simon, Zsolt. Magyarország és az Oszmán birodalom közötti kereskedelmi kapcsolatok a 16. század elejen. A baricsi es kölpényi harmincadok forgalma [ Trade relations between Hungary and the Ottoman Empire at the beginning of the sixteenth century. The trade at the thirtieth customs posts of Barics and Kölpényi]. PhD dissertation. ELTE, 2007.

58. Szakály, Ferenc. "Phases of Turco-Hungarian Warfare Before the Battle of Mohács (1365-1526)." Acta Orientalia Academiae Scientiarum Hungaricae 33 (1979): 65-111.

59. Szakály, Ferenc, Pál Fodor. "A kenyérmezei csata (1479. Október 13.)" [The Battle of Kenyérmező (13 October 1479)]. Hadtörténelmi Közleméynek 111 (1998): 309-48.

60. Szakály, Ferenc. "The Hungarian-Croatian Border Defense System and its Collapse." In From Hunyadi to Rákóczi: War and Society in Late Medieval and Early Modern Hungary. Edited by János M. Bak and Béla K. Király, 141158. Brooklyn: Brooklyn College Press, 1982.

61. Tagány, Karl. "Alte Grenzschutz-Vorrichtungen und Grenz-Ödland: gyepü und gyepüelve." Ungarische Jahrbücher 1(1921): 105-21.

62. Tardy, Lajos. Beyond the Ottoman Empire: 14th-16th century Hungarian Diplomacy in the East. Szeged: University of Szeged, 1978.

63. Thallóczy, Lajos. Povijest (banovine, grada i varoši) Jajca 1450.-1527. [History of the (banate, castle, and town) of Jajce 1450-1527]. Zagreb: Kraljevska zemaljska tiskara, 1916.

64. Tóth Norbert, Richárd Horváth, Tibor Neumann and Tamás Pálosfalviet, eds. Magyarország világi archontológiája 1458-1526. Vol. I - Főpapok és bárók [Hungarian lay archontology 1458-1490 - Prelates and barons ]. Budapest: MTA, 2016.

65. Toubert, Pierre. "Frontière et frontières: un objet historique." In Castrum 4. Frontière et peuplement dans le monde méditerranéen au Moyen Âge. Edited by Jean-Michel Poisson, 9-17. Rome and Madrid: École française de Rome and Casa de Velázquez, 1992.

66. Veszprémy, László. "Szabács ostroma (1475-1476)" [The siege of Šabac]. Hadtörténeti Közlemények 122 (2009): 36-61.

67. Woods, John E. The Aqquyunlu: Clan, Confederation, Empire. Salt Lake City: The University of Utah Press, 1999.

68. Zinkeisen, Johann Wilhelm. Geschichte des osmanischen Reiches in Europa. Vol. II. Gotha: Friedrich Andreas Perthes, 1854.

69. Zsoldos, Atilla. "Confinium és marchia (Az Árpád-kori határvédelem néhány intézményéröl)" [Confinium and marchia (Some institutions of border-protection of the Árpád period)]. Századok 134 (2000): 99-116. 
